\title{
Efficient Protocol for Introducing Regeneration of Adventitious Buds from Hypocotyl Explants in Jatropha curcas L.
}

\author{
Ying LIU ${ }^{1, a}$, Su-Fang NIU ${ }^{2, b}$, Jian-Nong LU ${ }^{1, c}$, Sen $\mathrm{CHEN}^{1, \mathrm{~d}}$, \\ Ya-Fei WANG ${ }^{1, \mathrm{e}}$, Hong-Bo ZHU ${ }^{1, \mathrm{f}}$, Lin-Feng LI ${ }^{1, \mathrm{~g}}$, \\ Yu-Zhen SHI ${ }^{1, \mathrm{~h}}$, Xue-Gui YIN ${ }^{1, \mathrm{i}_{*}}$ \\ ${ }^{1}$ Faculty of Agricultural Science, Guang Dong Ocean University, Haida Road \#1, \\ Mazhang District, 524088, Zhanjiang, Guangdong, P. R. China. \\ ${ }^{2}$ Faculty of Fisheries, Guang Dong Ocean University, Haida Road \#1, \\ Mazhang District, 524088, Zhanjiang, Guangdong, P. R. China. \\ aliuying85168@126.com, bwolf0487@126.com, 'lujnong@163.com, \\ dchensen0307@126.com, epangtuzifeifei@126.com, '39198351@qq.com, \\ '149327957@qq.com, 'shyzh1102@163.com, ìinxuegui@126.com
}

${ }^{*}$ Corresponding author

Keywords: Jatropha curcas; Hypocotyl explant; Regeneration; Rooting; Thidiazuron,.

\begin{abstract}
A new strategy of high concentration short duration treatment of Thidiazuron (TDZ) for enhancing adventitious buds formation from hypocotyl explants were attempted in Jatropha curcas. The best shoot buds induction (81.91\%) and number of buds per explant (10.16) were obtained from hypocotyl explants treated with $20 \mathrm{mg} / \mathrm{L}$ TDZ solution for $20 \mathrm{~min}$, followed by 30 days of culture on hormone-free MS medium. The elongated shoots initiated roots to become intact plantlets in rooting medium containing indole-3-butyric acid (IBA) and L-glutamine (Gln), and the results showed that the initiation and growth of roots were effectively stimulated with supplementing $16 \mathrm{mg} / \mathrm{L}$ Gln into the rooting medium, and having the best rooting rate (51.39\%). After acclimatization, an intact plantlet could usually be gained at 60 days of culture by using the culture protocol described in this study.
\end{abstract}

\section{Introduction}

Jatropha curcas L. is a sort of woody plant and pertains to the Euphorbiaceae family [1,2]. As is well-known that the latex from $J$. curcas contains alkaloids have been reported to contain medical composition and can be utilized to acquire pharmaceutical adjective constituents [3,4] and pesticides [5]. Nevertheless, the best known of this tree is the high oil yielding from its seeds (40\% to $60 \%$ ) [6]. Widespread interest in cultivation of $J$. curcas all over the world, because methyl ester extracted from $J$. curcas is suitable for production of biodiesel $[4,5,7,8]$.

The most major problem for $J$. curcas plants not being grown on a major scale is that the low and unstable seed production because of natural hybrid [9]. With the purpose of breeding excellent varieties, the method of genetic transformation of the species might be a feasible approach [10-13].

In a general way, adventitious shoot regeneration from the transformed receptors (explants) is a precondition in genetic transformation system. Moreover, it is reported that the tissue culture cycles of common regeneration protocols were quite time-consuming (usually 3-5 months) for gaining intact plant in most of the reports in J. curcas. Consequently, it is indispensable to exploit high-efficiency methods of tissue culture, which could accelerate mass production of good-quality implants materials and capacitate breed improvement by means of technique for gene engineering.

It was found that the regeneration of plants from different organs as explant sources had been implemented using tissue cultures protocols in J. curcas [14-19]. However, the regeneration efficiency of hypocotyl explants was barely satisfactory in J. curcas [20-23]. 


\section{Materials and Methods}

\section{Plant Materials}

The mature $J$. curcas seed coded M-19 were the material source in our study. All plants were cultivated at a farm in Haikou, China [24].

\section{Preparation of Explants}

Vigorously growing in vitro hypocotyl from 5 day old aseptic seedings were cut into in vitro hypocotyl explants of about $0.5 \mathrm{~cm}$ in length. Well-growing hypocotyl from 12 day old seedings were cut into in vivo hypocotyl explants of about 0.5 in length.

\section{Preparation of Thidiazuron (TDZ) Solution}

TDZ was dissolved into $1 \mathrm{~mol} / \mathrm{L} \mathrm{NaOH}$ to produce $0.2 \mathrm{mg} / \mathrm{mL}$ TDZ solution. And the solution was diluted with distilled water to generate the concentrations as follows: $0,10,20,30$ and $60 \mathrm{mg} / \mathrm{L}$. These were adjusted with $1 \mathrm{~mol} / \mathrm{L} \mathrm{HCl}$ to acquire a $\mathrm{pH}$ value range of 5.8-6.0, and filter-sterilized before being used for treating the hypocotyl explants.

\section{Dealing with the Hypocotyl Explants with TDZ Solution}

Hypocotyl explants were immersed in glass petri dishes supplemented with various concentrations $(0,10,20,30$ and $60 \mathrm{mg} / \mathrm{L})$ of TDZ solution for various time periods $(0,5,20,30$ and $40 \mathrm{~min})$. After treatment, the explants were transitorily put on sterile absorbent paper to soak excess amount of moisture.

\section{Preparation of Mediums and Culture Conditions}

Ordinary MS media was applied to overall tissue culture experiments in this study. All mediums had been included $2.5 \%$ sucrose and $0.6 \%$ agar, and tuned to $\mathrm{pH} 5.8-6.0$ with $1 \mathrm{~mol} / \mathrm{L} \mathrm{NaOH}$ before being autoclaved at $1.4 \mathrm{~kg} \mathrm{~cm}-2$ for 20 minutes. Unified culture conditions were applied in all experiments. All treatments were kept at $25 \pm 1^{\circ} \mathrm{C}$ under a $12 \mathrm{~h}$ photoperiod of $60-80 \mu$ mol m-2s-1 intensity (cool white fluorescent tubes).

\section{Regeneration of Adventitious Buds}

In order to induce adventitious buds regeneration, hypocotyl explants were placed onto hormone-free Murashige and Skoog's (MS) medium [25] after treated by TDZ solution for different time periods for 30 days. The explants were put on the mediums with their morphological up-side up vertically simply for comparative experiments. What's more, hypocotyl explants were also treated with conventional approach and horizontally inoculated onto MS medium including 0, 0.1, 0.3, 0.6 and $1.2 \mathrm{mg} / \mathrm{L}$ TDZ as reported anteriority [20-23].

\section{Elongation of Shoot-Buds}

The regenerated shoot-buds were transferred with the mother tissues (explants) together onto MS medium containing $0.5 \mathrm{mg} / \mathrm{L} \mathrm{BA}, 0.25 \mathrm{mg} / \mathrm{L}$ indole-3-acetic acid (IAA), $0.2 \mathrm{mg} / \mathrm{L}$ kinetin (KT) and $0.4 \mathrm{mg} / \mathrm{L}$ gibberellic acid $\left(\mathrm{GA}_{3}\right)$ for 15 days $[24,26]$.

\section{Rooting}

For the sake of inducing rooting of the elongated shoot-buds, shoots (at least $10 \mathrm{~mm}$ in length) were separated from the maternal tissues and inoculated them on MS medium contained $0.3 \mathrm{mg} / \mathrm{L}$ indole-3-butyric acid (IBA) and various concentrations (0, 2, 8, 16, 24 and $48 \mathrm{mg} / \mathrm{L}$ ) of L-glutamine (Gln) and the experimental results were recorded after cultivating 10, 20, 30 and 40 days. Gln solution was filter-sterilized and supplemented into the autoclaved medium as depicted anteriorly [27].

\section{Process of Transplant Acclimatization}

Regenerated plantlets were taken out from jars carefully, washed completely for wiping off 
residuary mediums, and then they were migration to plastic pots with germfree sand and soil at the ratio 1:1 and carpeted with plastic wrap for 15-20 days. Finally, the complete plants were moved to a conservatory (working Humidity $70-80 \%$ and temperature $25 \pm 3^{\circ} \mathrm{C}$ ) for further accumulation and growth.

\section{Data Analysis}

All experiments were established on a design of random factor method completely and repeated 3 times with 35 explants per treatment in the present study. 'Regeneration percentage' was computed by dividing the number of explants that regenerated shoot-buds with the amount of explants. 'Number of buds per explant' was computed by dividing the number of regenerated shoot-buds with the amount of hypocotyl explants that had regenerated buds. 'Length of shoot-buds' was computed by the average length of elongated shoots. 'Rooting percentage' was computed by dividing the number of shoots that had regenerated adventitious roots with the total amount of shoots used for inducing rooting. 'Number of roots per shoot' was computed by dividing the number of regenerated roots with the amount of shoots that had regenerated roots. 'Average root length' was computed by dividing length of all regenerated roots with the number of regenerated roots. Statistical analysis of the data was implemented by utilizing SPSS 17.0 soft ware. Furthermore, data in the same column followed by different letters was significantly different by Duncan's test at $p \leq 5 \%$ level. The experimental data was shown as means \pm SD (standard deviation) of 3 standalone experiments.

\section{Results}

\section{Regeneration of Shoot-Buds from Hypocotyl Explants with Conventional Techniques}

Hypocotyl explants were inoculated on MS medium supplemented with different concentrations of TDZ as reported anteriorly [20-23]. The results indicated that the highest centage of adventitious buds induction (24.73\%) and the maximum number of induced shoot-buds per explant (2.63) were investigated when $0.6 \mathrm{mg} / \mathrm{L} \mathrm{TDZ}$ was used (Table 1 and Fig. 1A). However, improving the TDZ concentration to exceed $0.6 \mathrm{mg} / \mathrm{L}$ would not obtain better results, so $0.6 \mathrm{mg} / \mathrm{L}$ TDZ was the most suitable concentration for the induction of shoot-buds (Table 1 and Fig. 1A). Furthermore, the quantity of regenerated buds per explants was considerably small, whilst majority of the regenerated shoot-buds were extremely tiny and underdeveloped. What's more, further elongation of shoot-buds was very difficult at $0.6 \mathrm{mg} / \mathrm{L}$ concentration (data not shown).

Table 1. Results of various TDZ concentrations on the regeneration of adventitious buds from hypocotyl explants in J. curcas after 30 days of culture.

\begin{tabular}{ccc}
\hline $\begin{array}{c}\text { TDZ concentration } \\
(\mathrm{mg} / \mathrm{L})\end{array}$ & $\begin{array}{c}\text { Regeneration } \\
\text { percentage }(\%)\end{array}$ & $\begin{array}{c}\text { Number of } \\
\text { buds per explant }\end{array}$ \\
\hline 0 & $0 \mathrm{~d}$ & $0 \mathrm{~d}$ \\
0.1 & $9.93 \pm 1.81 \mathrm{c}$ & $1.19 \pm 0.12 \mathrm{c}$ \\
0.3 & $18.80 \pm 1.93 \mathrm{~b}$ & $1.81 \pm 0.32 \mathrm{~b}$ \\
0.6 & $24.73 \pm 3.06 \mathrm{a}$ & $2.63 \pm 0.21 \mathrm{a}$ \\
1.2 & $17.97 \pm 2.38 \mathrm{~b}$ & $2.13 \pm 0.28 \mathrm{ab}$ \\
\hline
\end{tabular}

\section{Regeneration of Shoot-Buds from Hypocotyl Explants after Being Treated with TDZ Solution}

Hypocotyl explants were dealt with different concentrations of TDZ solution for 20 min before being placed onto basic MS medium free of hormone. The experimental results showed clearly that the protocol of treatment with TDZ solution was more efficient than conventional means on induction of shoot-buds regeneration from hypocotyl explants. Moveover, the highest percentage of adventitious buds induction (81.91\%) and the maximum number of induced shoot-buds per explant (10.16) were obtained on account of the utilization of $20 \mathrm{mg} / \mathrm{L} \mathrm{TDZ}$ solution (Table 2 and Fig. 1B) . 
When the concentrations of TDZ solution were not more than $20 \mathrm{mg} / \mathrm{L}$, the percentage of adventitious buds induction and the number of induced shoot-buds per explant were proportional to the TDZ concentrations directly. Nevertheless, the application of higher than $20 \mathrm{mg} / \mathrm{L}$ resulted in the percentage of shoot-buds regeneration significantly decreased (Table 2). Hence, the optimum TDZ concentration for adventitious buds induction was $20 \mathrm{mg} / \mathrm{L}$.

Table 2. Result of dealing with hypocotyl explants by different concentrations of TDZ solution for inducing adventitious buds regeneration in J. curcas after 30 days of culture.

\begin{tabular}{ccc}
\hline $\begin{array}{c}\text { TDZ solution } \\
\text { concentration(mg/L) }\end{array}$ & $\begin{array}{c}\text { Regeneration } \\
\text { percentage }(\%)\end{array}$ & $\begin{array}{c}\text { Number of } \\
\text { buds per explant }\end{array}$ \\
\hline 0 & $0 \mathrm{~d}$ & $0 \mathrm{e}$ \\
10 & $52.45 \pm 4.24 \mathrm{c}$ & $4.19 \pm 0.62 \mathrm{~d}$ \\
20 & $81.91 \pm 2.65 \mathrm{a}$ & $10.16 \pm 0.81 \mathrm{a}$ \\
30 & $64.44 \pm 3.85 \mathrm{~b}$ & $7.48 \pm 0.34 \mathrm{~b}$ \\
60 & $52.96 \pm 3.14 \mathrm{c}$ & $5.33 \pm 0.30 \mathrm{c}$ \\
\hline
\end{tabular}
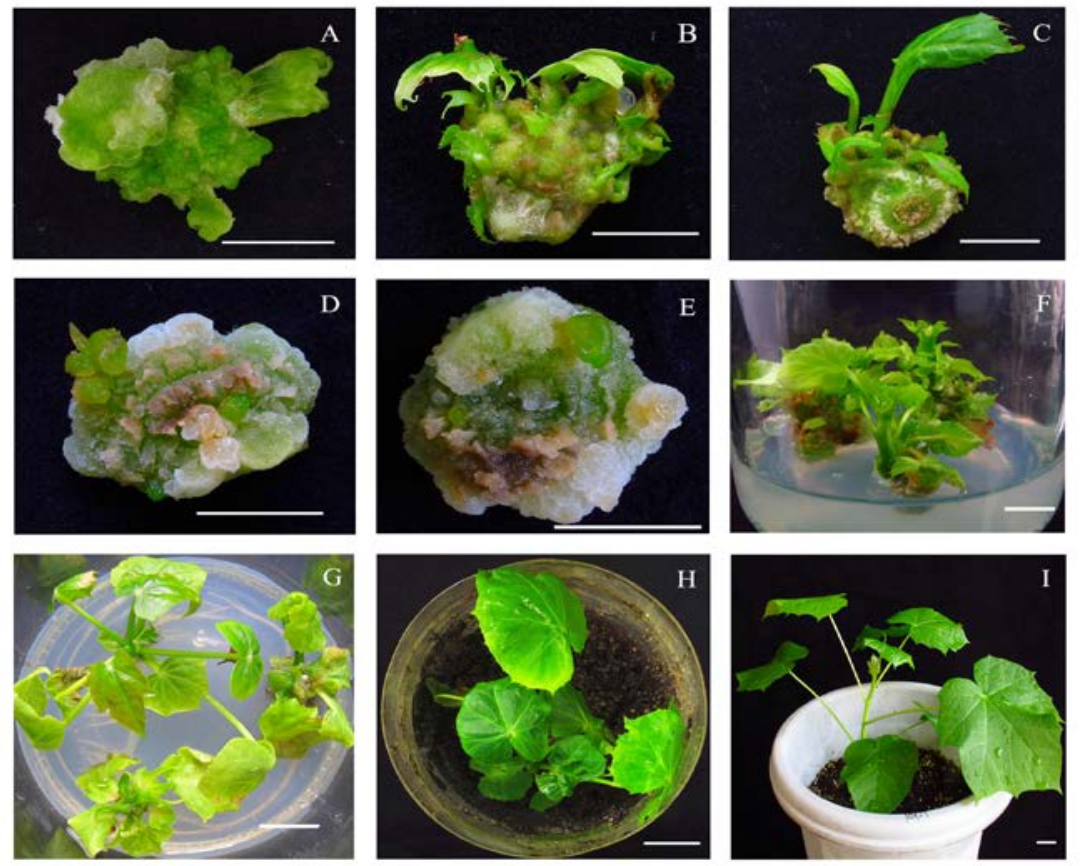

Fig. 1. Induction of shoot-buds, elongation and rooting of regenerated buds from hypocotyl explants in J. Curcas.

(A) Hypocotyl explants were placed onto MS medium supplemented with $0.6 \mathrm{mg} / \mathrm{L}$ TDZ for 30 days; hypocotyl explants in vitro were inoculated horizontally (B) and vertically (C), and in vivo hypocotyl explants were placed horizontally (D) and vertically (E) on hormone-free MS medium for

30 days after being dealt with $20 \mathrm{mg} / \mathrm{L}$ TDZ solution for $20 \mathrm{~min}$; (F) Elongation of regenerated adventitious buds in MS medium contained $0.25 \mathrm{mg} / \mathrm{L} \mathrm{KT,} 0.5 \mathrm{mg} / \mathrm{L}$ 6-BA, $0.25 \mathrm{mg} / \mathrm{L}$ IAA and 0.4 $\mathrm{mg} / \mathrm{L}$ GA3 for 15 days; (G) a regenerative plant in 1/2 MS medium included $0.3 \mathrm{mg} / \mathrm{L}$ IBA and 16 mg/L Gln for 20 days; (H) a intact plant acclimatization in plastic bottle for 10 days and (I) in a pot for further growth and development for 50 days. (bar $=1 \mathrm{~cm}$ )

For purpose of investigating the effect of duration of TDZ solution treatment on shoot-buds induction, hypocotyl explants were dealt with $20 \mathrm{mg} / \mathrm{l} \mathrm{TDZ}$ solution for different period of time previous to inoculate explants onto hormone-free MS medium. When the explants were dealt with $20 \mathrm{mg} / \mathrm{L}$ TDZ solution for $5 \mathrm{~min}$ before culture, the induction percentage of regenerated buds was $53.61 \%$, and the number of shoot-buds per explants was 5.46 (Table 3). This result was superior to the best consequence gained via applying general culture protocols (Table 1). Dealing with the 
explants with $20 \mathrm{mg} / \mathrm{L}$ TDZ solution for 20 min was the optimum condition and it acquired the highest percentage of regeneration (81.91\%) and the maximum number of regenerated shoot-buds per explant (10.16) (Table 3 and Fig. 1B). When the explants were dealt with $20 \mathrm{mg} / \mathrm{l} \mathrm{TDZ}$ for time of duration more than $20 \mathrm{~min}$, i.e. 30 and $60 \mathrm{~min}$, the frequency of shoot regeneration was reduced markedly; the percentage of adventitious buds induction was altered from $61.51 \%$ to $72.36 \%$, and the quantity of induced shoot-buds per explant was varied from 6.99 to 8.25 (Table 3).

Table 3. Result of dealing with explants with TDZ solution for different durations on shoot-buds regeneration from hypocotyl explants of $J$. curcas after 30 days of culture.

\begin{tabular}{ccc}
\hline $\begin{array}{c}\text { Treatment } \\
\text { duration }(\min )\end{array}$ & $\begin{array}{c}\text { Regeneration } \\
\text { percentage }(\%)\end{array}$ & $\begin{array}{c}\text { Number of } \\
\text { buds per explant }\end{array}$ \\
\hline 0 & $0 \mathrm{~d}$ & $0 \mathrm{~d}$ \\
5 & $53.61 \pm 3.37 \mathrm{~d}$ & $5.46 \pm 0.52 \mathrm{~d}$ \\
20 & $81.91 \pm 2.65 \mathrm{a}$ & $10.16 \pm 0.81 \mathrm{a}$ \\
30 & $72.36 \pm 3.48 \mathrm{~b}$ & $8.25 \pm 0.47 \mathrm{~b}$ \\
40 & $61.51 \pm 4.81 \mathrm{c}$ & $6.99 \pm 0.32 \mathrm{c}$ \\
\hline
\end{tabular}

\section{Comparison the Regeneration Effect of Inoculation Methods on Culture}

For the sake of study the effect of inoculation orientation (horizontal or vertical) on shoot-buds induction, the hypocotyl explants were inoculated onto hormone-free MS medium horizontally or vertically after being treated with $20 \mathrm{mg} / \mathrm{L}$ TDZ for $20 \mathrm{~min}$. The results of our study showed distinctly that the way of placing the explants horizontally on the medium for regeneration was much more advantageous than inoculating the explants vertically (Table 4, Fig. 1B-D). The number of induced adventitious buds per explant was altered from 2.04 to 10.16 in the horizontal position and 1.17 to 4.27 in the vertical position, whilst the percentage of adventitious buds induction was varied from 25.70 to $81.91 \%$ in the horizontal position and 11.03 to $38.51 \%$ in the vertical position (Table 4, Fig. 1B-D).

Table 4. Results of the explants orientation on the regeneration of shoot-buds from hypocotyl explants in $J$. curcas after 30 days of culture.

\begin{tabular}{clcc}
\hline Explant source & Orientation & Regeneration percentage (\%) & Number of buds per explant \\
\hline In vitro & Horizontal & $81.91 \pm 2.65 \mathrm{a}$ & $10.16 \pm 0.81 \mathrm{a}$ \\
& Vertical & $38.51 \pm 3.40 \mathrm{~b}$ & $4.27 \pm 0.45 \mathrm{~b}$ \\
& & & \\
In vivo & Horizontal & $25.70 \pm 2.59 \mathrm{a}$ & $2.04 \pm 0.25 \mathrm{a}$ \\
& Vertical & $11.03 \pm 1.81 \mathrm{~b}$ & $1.17 \pm 0.11 \mathrm{~b}$ \\
\hline
\end{tabular}

\section{Results of L-glutamine (GIn) on rooting of shoots}

Though the elongated shoot-buds could be induced rooting in the MS medium containing $0.3 \mathrm{mg} / \mathrm{L}$ IBA, the rooting efficiency was comparatively low, and the highest rooting induction efficiency was 23.68\% (Table 5 and Fig. 1F). Our results indicated that the activation and growth of roots were stimulated effectively attributing to supplement with Gln at specific concentrations into the mediums, and the greatest rooting rate (51.39\%) was obtained when $16 \mathrm{mg} / \mathrm{L} \mathrm{Gln}$ having been applied into MS medium contained $0.3 \mathrm{mg} / \mathrm{L}$ IBA in the present study (Table 5). However, the regeneration of roots was inhibited significantly when the concentrations of added Gln was exceed $16 \mathrm{mg} / \mathrm{L}$ (Table 5 and Fig. 1G). When the elongated shoos were inoculated into the MS medium containing only $16 \mathrm{mg} / \mathrm{L}$ Gln, the rooting rate of the elongated shoot buds was merely $11.14 \%$ at 40 days of culture (Table 5).

Regenerated plantlets were acclimatized in plastic bottle for 15 days (Fig. $1 \mathrm{H}$ ) and then transplanted successfully into the soil for normal growth (Fig. 1I). 
Table 5. Results of different L-glutamine concentrations on the rooting of regenerated shoots from hypocotyl explants in J. curcas.

\begin{tabular}{|c|c|c|c|c|}
\hline $\begin{array}{l}\text { Culture } \\
\text { time } \\
\text { (days) }\end{array}$ & $\begin{array}{c}\text { Gln } \\
\text { concentration } \\
(\mathrm{mg} / \mathrm{L})\end{array}$ & $\begin{array}{c}\text { Rooting } \\
\text { percentage } \\
(\%)\end{array}$ & $\begin{array}{c}\text { Number of } \\
\text { roots per } \\
\text { shoot }\end{array}$ & $\begin{array}{l}\text { Average } \\
\text { root length } \\
(\mathrm{cm})\end{array}$ \\
\hline \multirow[t]{8}{*}{10} & 0 & $8.36 \pm 2.44 d$ & $1.27 \pm 0.25 b$ & $0.65 \pm 0.23 b$ \\
\hline & 2 & $9.17 \pm 2.86 d$ & $1.33 \pm 0.29 b$ & $0.68 \pm 0.15 b$ \\
\hline & 8 & $23.77 \pm 4.25 b$ & $2.25 \pm 0.25 a$ & $0.92 \pm 0.24 b$ \\
\hline & 16 & $31.25 \pm 3.24 \mathrm{a}$ & $2.35 \pm 0.36 a$ & $1.33 \pm 0.19 a$ \\
\hline & 24 & $21.93 \pm 2.98 b c$ & $2.09 \pm 0.23 a$ & $1.27 \pm 0.18 \mathrm{a}$ \\
\hline & 48 & $16.90 \pm 2.03 c$ & $1.32 \pm 0.33 b$ & $0.91 \pm 0.10 \mathrm{~b}$ \\
\hline & CK1* & $0 \mathrm{e}$ & 0c & 0c \\
\hline & CK2** & $5.63 \pm 2.05 d$ & $1.33 \pm 0.58 b$ & $0.65 \pm 0.10 \mathrm{~b}$ \\
\hline \multirow[t]{8}{*}{20} & 0 & $15.32 \pm 1.22 \mathrm{c}$ & $3.11 \pm 0.19 \mathrm{c}$ & $1.61 \pm 0.14 \mathrm{c}$ \\
\hline & 2 & $16.59 \pm 5.28 c$ & $3.31 \pm 0.34 \mathrm{c}$ & $1.66 \pm 0.15 c$ \\
\hline & 8 & $32.63 \pm 4.52 b$ & $4.39 \pm 0.41 b$ & $2.42 \pm 0.25 b$ \\
\hline & 16 & $38.16 \pm 4.63 a$ & $5.11 \pm 0.28 \mathrm{a}$ & $2.92 \pm 0.32 \mathrm{a}$ \\
\hline & 24 & $30.98 \pm 2.14 b$ & $4.29 \pm 0.29 b$ & $2.56 \pm 0.27 \mathrm{ab}$ \\
\hline & 48 & $18.57 \pm 1.54 \mathrm{c}$ & $3.25 \pm 0.43 c$ & $2.37 \pm 0.24 b$ \\
\hline & CK1 & $0 \mathrm{e}$ & $0 \mathrm{e}$ & od \\
\hline & CK2 & $7.08 \pm 2.22 \mathrm{~d}$ & $1.50 \pm 0.5 \mathrm{~d}$ & $1.33 \pm 0.23 \mathrm{c}$ \\
\hline \multirow[t]{8}{*}{30} & 0 & $22.09 \pm 2.98 d$ & $3.57 \pm 0.40 \mathrm{~d}$ & $3.37 \pm 0.31 c$ \\
\hline & 2 & $24.12 \pm 3.40 \mathrm{~d}$ & $3.85 \pm 0.51 d$ & $3.50 \pm 0.29 b c$ \\
\hline & 8 & $35.24 \pm 3.56 b c$ & $4.99 \pm 0.61 \mathrm{c}$ & $4.01 \pm 0.30 \mathrm{~b}$ \\
\hline & 16 & $49.94 \pm 2.09 a$ & $5.91 \pm 0.31 \mathrm{a}$ & $4.77 \pm 0.43 a$ \\
\hline & 24 & $39.77 \pm 4.36 b$ & $5.36 \pm 0.21 \mathrm{ab}$ & $4.63 \pm 0.29 a$ \\
\hline & 48 & $30.83 \pm 2.21 c$ & $3.90 \pm 0.63 d$ & $3.53 \pm 0.35 b c$ \\
\hline & CK1 & of & of & $0 \mathrm{e}$ \\
\hline & CK2 & $9.97 \pm 1.81 \mathrm{e}$ & $1.67 \pm 0.29 \mathrm{e}$ & $1.78 \pm 0.18 d$ \\
\hline \multirow[t]{8}{*}{40} & 0 & $23.68 \pm 1.39 d$ & $4.53 \pm 0.42 \mathrm{~d}$ & $3.75 \pm 0.50 \mathrm{c}$ \\
\hline & 2 & $25.87 \pm 2.16 \mathrm{~d}$ & $4.73 \pm 0.64 d$ & $3.83 \pm 0.45 c$ \\
\hline & 8 & $36.75 \pm 4.97 c$ & $5.61 \pm 0.23 b c$ & $4.51 \pm 0.26 b$ \\
\hline & 16 & $51.39 \pm 1.21 \mathrm{a}$ & $6.43 \pm 0.25 a$ & $5.37 \pm 0.39 a$ \\
\hline & 24 & $42.81 \pm 4.36 b$ & $5.89 \pm 0.18 \mathrm{ab}$ & $5.03 \pm 0.21 \mathrm{ab}$ \\
\hline & 48 & $32.50 \pm 3.01 c$ & $4.93 \pm 0.44 \mathrm{~cd}$ & $3.86 \pm 0.30 c$ \\
\hline & CK1 & of & of & $0 \mathrm{e}$ \\
\hline & CK2 & $11.44 \pm 2.52 \mathrm{e}$ & $1.72 \pm 0.25 \mathrm{e}$ & $1.82 \pm 0.19 \mathrm{~d}$ \\
\hline
\end{tabular}

*CK1: hormone-free MS medium; **CK2: MS medium contained 16 mg/L Gln.

\section{Discussion}

Direct inoculation of hypocotyl explants onto mediums containing cytokinin such as TDZ at low concentrations (usually $0.05-1 \mathrm{mg} / \mathrm{L}$ ) is the conventional culture protocols for inducing regeneration of shoot-buds in J. curcas [20-23]. However, the conventional methods showed low regeneration efficiency and the shoot-buds were hard to elongation sequentially. The regeneration frequency and the formation of bigger buds were facilitated due to apply the method of dealing with hypocotyl explants with high concentration of TDZ solution for a short time before placing onto hormone-free MS medium. Furthermore, then continued to culture the regenerated buds revealed that those 
shoot-buds were readily elongated.

Cytokinin was a key factor for adventitious buds induction in plant tissue culture universally [14, 19, 28, 29]. TDZ was a plant growth regulator belonged to the cytokinin family. Our results indicated that cytokinin might be needed for a short time in the process of induction of adventitious buds after treatment with high concentration of TDZ solution. Nevertheless, it's unclear that how TDZ played a part in inducing of adventitious buds in our protocols. Our previous research found that the frequency of adventitious buds regeneration from hypocotyl explants was increased markedly with high concentrations of BA solution treatment before inoculating the explants on hormone-free MS medium in soybean [30]. These results implied that although various cytokinins should be detected for optimum results, our culture protocols could be large-scale applied to other plant species.

IBA was subject to the auxin family and deemed to be contributing in the rooting of $J$. curcas definitely [9,31-33]. The rooting efficiency was relatively low when the shoots were induced to rooting in the MS medium just included $0.3 \mathrm{mg} / \mathrm{L}$ IBA. Gln was regarded as a endogenous amino acids, which supplied nitrogen for the biosynthesis of nucleic acids and other $\mathrm{N}$-compounds and participated in plant metabolism [34]. Therefore, Gln was used in mediums as an organic nitrogen source frequently [35]. Some reports indicated that exogenous Gln might have some beneficial influenced on rooting of shoots in numerous plants [36-38]. Our study results suggested that the efficiency of shoots rooting could be improved dramaticlly attributing to applying the exogenous Gln in J. curcus.

In the present study, the proliferation and elongation of shoots were implemented synchronously, and then the period for obtaining intact plantlets was cut down signally without compromising the quality and quantity of regenerated buds. On account of the modified shoots elongation and efficient roots induction, an intact plantlet could be acquired in 60 days of culture via applying the new protocol described above, while there were time-consuming by conventional methods needed 90-140 days of culture [20,23].

\section{Conclusion}

In short, a high efficiency in vitro culture method for achieving regenerated plantlets was founded in the present study. This efficient and reproducible protocol would be beneficial for increasing quantity of regenened plants and could be applied to generating transgenic plants via Agrobacterium mediated transformation.

\section{Acknowledgements}

This work were supported by the National Science Foundation of P. R. China (31271759), the Project of Science and Technology of Guangdong province (2013B060400024 and 2014A020208116), the Program for Scientific Research Start-up Funds of Guangdong Ocean University, the Project of Science and Technology of Zhangjiang city (2016B101), and the Project of Enhancing School with Innovation of Guangdong Ocean University (2015KQNCX054).

\section{References}

[1] B. Schmook, L. Serralta-Peraza, Jatropha curcas: distribution and uses in the Yucatan Peninsula of Mexico, In Gubitz, G. M., Mittelbach, M., and Trabi, M., (ed.), Biofuels and industrial products from Jatropha curcas, Dbv-Verlag, Graz, 1997, pp. 53-57.

[2] A.S. Helmy Attaya, D. Geelen, H. Belal and A. El-Fatah, Progress in Jatropha curcas tissue culture, Am. -Eurasian J. Sustain. Agric. 6 (2012) 6-13.

[3] R.C. Gupta, Pharmacognostic studies on 'Dravanti'. Part I. Jatropha curcas Linn, Proc. Plant Sci. 94 (1985)65-82. 
[4] K. Openshaw, A review of Jatropha curcas: an oil plant unfulfilled promise, Biomass Bioenerg. 19 (2000) 1-15.

[5] K.O. Adebowale, C.O. Adedire, Chemical composition and insecticidal properties of the underutilized Jatropha curcas seed oil, Afr. J. Biotechnol. 10 (2006) 901-906.

[6] A.A.A. Liberalino, E.A. Bambirra, T. Moraes-Santos and E. C. Vieira, Jatropha curcas L. seeds: chemical analysis and toxicity, Arq. Biol. Technol. 31 (1998) 539-550.

[7] R. Banerji, A.R. Chowdhury, G. Misra, G. Sudarsanam, S.C. Verma, G.S. Srivastava, Jatropha seed oils for energy, Biomass. 8 (1985) 277-282.

[8] A. Ghosh, D.R. Chaudhary, M.P. Reddy, S.N. Rao, J. Chikara, J.B. Pandya, J.S. Patolia, M.R. Gandhi, S. Adimurthy, N. Vaghela, S. Mishra, M.R. Rathod, A.R. Prakash, B.D. Shethia, S.C. Upadhyay, V. Balakrishna, C.R. Prakash and P.K. Ghosh, Prospects for Jatropha methyl ester (biodiesel) in India, Int. J. Environ Stud. 64 (2007) 659-674.

[9] A. Singh, M.P. Reddy, J. Chikara and S. Singh, A simple regeneration protocol from stem explants of Jatropha curcas-a biodiesel plant, Ind. Crops Prod. 31 (2010) 209-213.

[10] M.R. Li, H.Q. Li, H.W. Jiang, X.P. Pan, G.J. Wu, Establishment of an Agrobacterium-mediated cotyledon disc transformation method for Jatropha curcas, Plant Cell Tiss. Organ. Cult. 92 (2008) 173-181.

[11] Y. He, V. Pasapula, X. Li, R. Lu, B. Niu, P. Hou, Y. Wang, Y. Xu, F. Chen, Agrobacterium tumefaciens-mediated transformation of Jatropha curcas: factors affecting transient transformation efficiency and morphology analysis of transgenic calli, Silvae Genet. 58 (2009) 123-128.

[12] M. Kajikawa, K. Morikawa, M. Inoue, U. Widyastuti, S. Suharsono, A. Yokota, K. Akashi, Establishment of bispyribac selection protocols for Agrobacterium tumefaciens and Agrobacterium rhizogenes mediated transformation of the oil seed plant Jatropha curcas L., Plant Biotechnol. 29 (2012) 145-153.

[13] J. Qu, H.Z. Mao, W. Chen, S.Q. Gao, Y.N. Bai, Y.W. Sun, Y.F. Geng, J. Ye, Development of marker-free transgenic Jatropha plants with increased levels of seed oleic acid, Biotechnol. Biofuels. 5 (2012) 1-11.

[14] V. Khurana-Kaul, S. Kachhwaha, S.L. Kothari, Direct shoot regeneration from leaf explants of Jatropha curcas in response to thidiazuron and high copper contents in the medium, Biol. Plant. 54 (2010) 369-372.

[15] N. Kumar, M.P. Reddy, Plant regeneration through the direct induction of shoot buds from petiole explants of Jatropha curcas: a biofuel plant, Ann. Appl. Biol. 156 (2010) 367-375.

[16] N. Khemkladngoen, J. Cartagena, N. Shibagaki and K. Fukui, Adventitious shoot regeneration from juvenile cotyledons of a biodiesel producing plant Jatropha curcas L., J. Biosci. Bioeng. 111 (2011) 67-70.

[17] N. Kumar, K.G. Vijayanand, M.P. Reddy, In vitro regeneration from petiole explants of non-toxic Jatropha curcas, Ind. Crops Prod. 33 (2011) 146-151.

[18] Q. Wei, W.D. Lu, Y. Liao, S.L. Pan, Y. Xu, L. Tang and F. Chen, Plant regeneration from epicotyl explants of Jatropha curcas, J. Plant Physiol. Mol. Biol. 30 (2004) 475-478.

[19] N. Kumar and M.P. Reddy, Thidiazuron (TDZ) induced plant regeneration from cotyledonary petiole explants of elite genotypes of Jatropha curcas: A candidate biodiesel plant, Ind. Crops. Prod. 39 (2012) 62-68. 
[20] M. Sujatha and N. Mukta, Morphogenesis and plant regeneration from tissue cultures of Jatropha curcas, Plant Cell Tiss. Organ Cult. 44(1996) 135-141.

[21] R. Soomro, R.A. Memon, Establishment of callus and suspension culture in Jatropha curcas, Pak. J. Bot. 39 (2007) 2431-2441.

[22] Y. He, X. Guo, R. Lu, B. Niu, V. Pasapula, P. Hou, F. Cai, Y. Xu, F. Chen, Changes in morphology and biochemical indices in browning callus derived from Jatropha curcas hypocotyls, Plant Cell Tiss. Organ Cult. 98 (2009) 11-17.

[23] S. Sharma, N. Kumar, M.P. Reddy, Regeneration in Jatropha curcas: Factors affecting the efficiency of in vitro regeneration, Ind. Crops. Prod. 34 (2011) 943-951.

[24] Y. Liu, X. Tong, W. Hui, T. Liu, X. Chen, J. Li, C.X. Zhuang, Y.S. Yang and Z.L. Liu, Efficient culture protocol for plant regeneration from petiole explants of physiologically mature trees of Jatropha curcas L., Biotechnol. Biotec. Eq. 29 (2015) 479-488.

[25] T. Murashige, F. Skoog, A revised medium for rapid growth and bioassays with tobacco tissue cultures, Physiol. Plant. 15 (1962) 473-479.

[26] A.C. Deore and T.S. Johnson, High-frequency plant regeneration from leaf-disc cultures of Jatropha curcas L.: an important biodiesel plant, Plant Biotech. Rep. 2 (2008) 10-15.

[27] E.L. Pedrotti, C. Jay-Allemand, P. Doumas, D Cornu, Effect of autoclaving amino acids on in vitro rooting response of wild cherry shoot, Sci. Hortic. 57 (1994) 89-98.

[28] T. Jha, P. Mukherjee, M.M. Datta, Somatic embryogenesis in Jatropha curcas Linn., an important biofuel plant, Plant Biotechnol. Rep. 1 (2007) 135-140.

[29] S. Rajore, A. Batra, An alternative source for regenerable organogenic callus induction in Jatropha curcas, Ind. J. Biotechnol. 6 (2007) 545-548.

[30] Y. Liu, L. Yu, Q. Zhang, H. Nian, Z.F. Guo and Y.S. Yang, High concentration short duration treatment of benzyladenine stimulates adventitious bud regeneration from hypocotyl explants in soybean, Adv. Mater. Res. 647 (2012) 331-335.

[31] M.M. Datta, P. Mukherjee, B. Ghosh, T.B. Jha, In vitro clonal propagation of biodiesel plant (Jatropha curcas L.), Curr. Sci. 93 (2007) 1438-1442.

[32] A.C. Deore, T.S. Johnson, High-frequency plant regeneration from leaf-disc cultures of Jatropha curcas L: an important biodiesel plant, Plant Biotech. Rep. 2 (2008) 10-15.

[33] S. Kochhar, S.P. Singh, V.K. Kochhar, Effect of auxins and associated biochemical changes during clonal propagation of the biofuel plant Jatropha curcas, Biomass Bioenerg. 32 (2005) 1136-1143.

[34] G. Coruzzi, R. Last, Amino acids, In: Buchanan B, Groissem W, Jones R, (eds), Biochemistry \& Biology of Plants. American Society of Plant Physiologists, USA, 2000, pp. 358-410.

[35] C.I. Franklin, R.A. Dixon, Initiation and maintenance of callus and cell suspension cultures, In: Dixon RA, Gonzales RA (eds), Plant Cell Culture-a practical approach, 2nd edn. Oxford University Press Inc., New York, USA, 1994, pp. 1-29.

[36] K. Kaur, B. Verma, U. Kant, Plants obtained from the Khair tree (Acacia catechu Willd.) using mature nodal segments, Plant Cell Rep. 17 (1998) 427-429.

[37] D.Y. Xie, Y. Hong, In vitro regeneration of Acacia mangium via organogenesis, Plant Cell Tiss. Organ Cult. 66 (2001) 167-173.

[38] J.J. Liu, Effect of glutamine, lanthanum chloride on the rooting and POD expression of Dendrobium, An hui Agri. Sci. Bull. 16 (2010) 47-49. (in Chinese) 